\title{
The Impact of Local Community Participation on Branding Ethnic Tourism Destination: A Case Study of House Renovation in Jiaju Tibetan Village
}

\author{
Xianmin Mai', Chuntao $\mathrm{Wu}^{2 *}$, Tingting Zhang1, Zhixiang Zhou1, Haiyan Zhong1 \\ ${ }^{1}$ School of Urban Planning \& Architecture, Southwest Minzu University, Chengdu, China \\ ${ }^{2}$ School of Tourism, Sichuan University, Chengdu, China \\ Email: ^2045800655@qq.com
}

How to cite this paper: Mai, X.M., Wu, C.T., Zhang, T.T., Zhou, Z.X. and Zhong, H.Y. (2019) The Impact of Local Community Participation on Branding Ethnic Tourism Destination: A Case Study of House Renovation in Jiaju Tibetan Village. Open Journal of Social Sciences, 7, 178-189. https://doi.org/10.4236/jss.2019.71016

Received: December 13, 2018

Accepted: January 15, 2019

Published: January 18, 2019

Copyright $\odot 2019$ by author(s) and Scientific Research Publishing Inc. This work is licensed under the Creative Commons Attribution International License (CC BY 4.0).

http://creativecommons.org/licenses/by/4.0/

\begin{abstract}
Jiaju Tibetan Village, located in Danba country, Sichuan province, is a newly developed ethic tourism destination. Based on the case study of house renovation and reconstruction, this paper studies the processes of local community participating in tourism development, and analyzes the impacts of local community's participation on forming destination image as well as destination brand. The study methods applied in this paper are building measurement, questionnaire survey and interview with villagers. The results show that villagers have focused on selecting the icons of Gyarong Tibetan culture during the process of house re-construction and presented these icons to the tourists. It is found out that local community has contributed to Jiaju village by selecting a plain destination image and building a higher quality brand. Also, villagers have improved their living environment through the house reconstruction.
\end{abstract}

\section{Keywords}

House Reconstruction, Destination Management, Host Community, Destination Images, Ethnic Tourism, Village

\section{Introduction}

Jiaju Tibetan Village is located at Danba county, Sichuan province in China. It covers an area of about 5 square kilometers. It is a typical Gyarong Tibetan Village, mainly including 3 hamlets, and most of the residents are Gyarong Tibetan. Jiaju means "100 families" in Tibetan language, and according to our field inves- 
tigation, there are totally 149 families in Jiaju Tibetan Village. The Gyarong Tibetan dwellings in the village are colorful and unique in shape, and are laid out along the hillside in a free-form layout. It was listed as one of the 6 most beautiful villages of China by Chinese National Geographic in 2005.

Because of its remote geographical position, this village keeps a relatively intact landscape for a long time. At the end of the 20th century, with the advent of a small amount of self-help tourists, a budding tourism development has begun in Jiaju Tibetan Village. The government compiled the Tourism Development Planning Outline in the year 2000, started to build a rural road in 2001, and began selling tickets for entering the village in 2002. The government has also put forward a "Reformation and Construction" project to encourage villagers to remodel the interior of the houses, for which the villagers are responsible for the cost by themselves. According to the introduction of the village head Gui Hua, in 2011, more than 98 houses has engaged in the work of the tourist reception. At the same time, the amount of tourists increased from less than 100 people per year in 1999 to more than 100 thousands in 2012.

As a newly developed ethnic tourism destination, Jiaju become a hotspot of scholars to study. Yun Liu (2007) argues that tourism has a positive effect on the community, but causes community disorganization problems at the same time [1]. Wang Liu uses the model of "Tragedy of the commons", "prisoners' dilemma" and "collective action logic" to explain the causes and problems of community participation in tourism (Wang, 2010) [2]. Ying and Zheng Long (2012) proposed some measures to further improve the level of Jiaju Tibetan Village community participation, such as strengthening the legislation, the ability of community residents to participate in community affairs, and cultivating the importance of civil community organizations, etc. [3]. Jie, Rujia and Yong (2013) analyzed the phenomenon of Jiaju Tibetan Village tourism and social conflict [4]. Yun (2014) put forward that we should stand in the whole group of village of residence and resident villages in the view of production and living for the overall protection. Scholars have paid attention to the impacts of the tourism development of community, and several scholars have studied the promoting effects of community participation in tourism development [5].

Based on analysis of the perception and attitudes to tourism development of local residents, this paper discusses the role of community participation in ethnic tourism destination brand building. The Gyarong Tibetan houses have distinctive shape and bright color, in harmony with the natural environment, which are the important tourist attractions. Through the long term natural and cultural selection, Jiaju has developed a kind of unique architectural form to adapt to the local natural environment (Ji, 2005) [6]. When the home inns were promoted by the local government, it is regulated for fire safety control, tableware hygiene, service fees and other standards, but it is not specified for the way of house extension, structure, decoration and settings, etc. Therefore, the way how local residents built and decorated their houses, can show the process and contents 
how they properly chose the regional symbols, helped to form a destination brand and introduced it to tourists.

The methods applied in this research include building surveying and mapping, the questionnaire survey and interview of the residents. In August 2013 and February 2014, we conducted surveying and mapping in Jiaju village, especially paying attention to the extension parts of houses after 2005. The build method, construction characteristics and usage situation were summed up. In February 2014, questionnaires and interviews with local residents were done, with 41 valid questionnaires and 5 interviews completed. The impacts of house transformation to the community were studied. The contents of the questionnaire included the villagers attitudes to relations of tourism development and the traditional architectural landscape, the life satisfaction, the modification of the Tibetan village, the elements of the influence of reforming houses, the most distinctive features of the local culture, and the most characteristics local elements, etc.

\section{Literature Review}

\subsection{Ethnic Cultural Tourism}

Ethnic tourism research generally belongs to the category of cultural tourism research (Melanie, 2009) [7]. Cultural tourism is a travel for people to know about other's life and thought (Jufeng, 2005) [8]. Melanie K. Smith (2009) divided cultural tourism into seven categories: heritage tourism, art tourism, creative tourism, urban cultural tourism, rural tourism, experiential cultural tourism and indigenous cultural tourism [7]. Among them, the indigenous cultural tourism includes ethnic tourism, tribal tourism, native tourism and aboriginal tourism. According to the type of tourist attractions, the cultural tourism also can be sub-divided into seven types: hill tribes hiking, wildlife and national parks, tropical rain forests and forest ecological tourism, desert hiking, arctic and arctic tourism, cultural heritage tourism, rural tourism.

In China, ethnic village tourism is also considered as a kind of cultural tourism. Its main type is rural tourism, also known as the "ethnic village tourism". The "Ethnic Villages Tourism" is a kind of tourism activity which takes the rural ethnic minority community as a tourist destination, takes the humanities and the natural scenery as a tourist attraction, experiences the heterogeneous culture, pursuits the simple life, and meets motivation of "novelty, difference, pleasure and knowledge". Therefore, ethnic minority regions mostly rely on the natural landscape, building, ethnic culture to develop tourism products. The local tourism products are mainly the deduction or experience of humanities landscape or ethnic customs, and the tourism brand construction is usually rather weak. In the tourism developing Area as Jiaju Tibetan village, tourism resources can be divided into two types: the tangible assets (such as natural landscape, farmland, traditional architecture) and the intangible assets (such as history, culture and legend anecdotes etc.) (Yun, 2014) [5]. As a carrier of the inheritance of ethnic 
culture, the local residents are also an important part of tourism resources (Wang and $\mathrm{Wu}, 2008)$ [9].

\subsection{Destination Branding}

Tourism brand is the key competitive factor of tourism destination (Ritchie and Grouch, 2000) [10]. Tourism destination branding is a process that an area forms a unique identity and individuality (Morrison and Anderson, 2002) [11]. Its main content is to build a positive destination image to distinguish and highlight somewhere (La, 2002) [12]. The personality brand, the flagship construction and the festival brand are the most important regional brand marketing techniques (Kawaratzis and Ashworth, 2005) [13]. Hankinson points out that the destination branding is also a continuous process from the perspective of planning (Hankinson, 2007) [14]. General marketing always starts from a new product, but the tourism destination marketing always starts from an old product. The tourist activities mostly depend on the local and original customs, geographical environment, etc. The production is almost not influenced by the market, and is usually carried on disorderly. Destination needs to be continuously planned and developed, in order to satisfy the interests of a large number of stakeholders and autonomous organization.

\subsection{Community Participation in the Destination Branding Process}

Destination branding process involves many stakeholders, such as local residents, investors, employees, students, retirees, tourists, media and public opinion leaders, entrepreneurs, services, foreign leaders and export buyers, etc. (Gilmore, 2002) [15]. Destination branding is usually a top-down process. The core stakeholders in the process of destination branding include local residents (including tourism practitioners and local social members), entrepreneurs and visitors (Figure 1) (García, Gómez and Molina, 2012) [16]. Local residents contribute to the destination branding, for they directly contact with tourists, and help to choose or recommend products to tourists (Freire, 2009) [17]. In one study of the Japanese Hiroshima tourism, Chuntao, Caroline and Yoshitsugu (2014) points out that local residents led the renovation of Hiroshima city to meet the tourists' requirements, and local residents are the backbone of reshaping
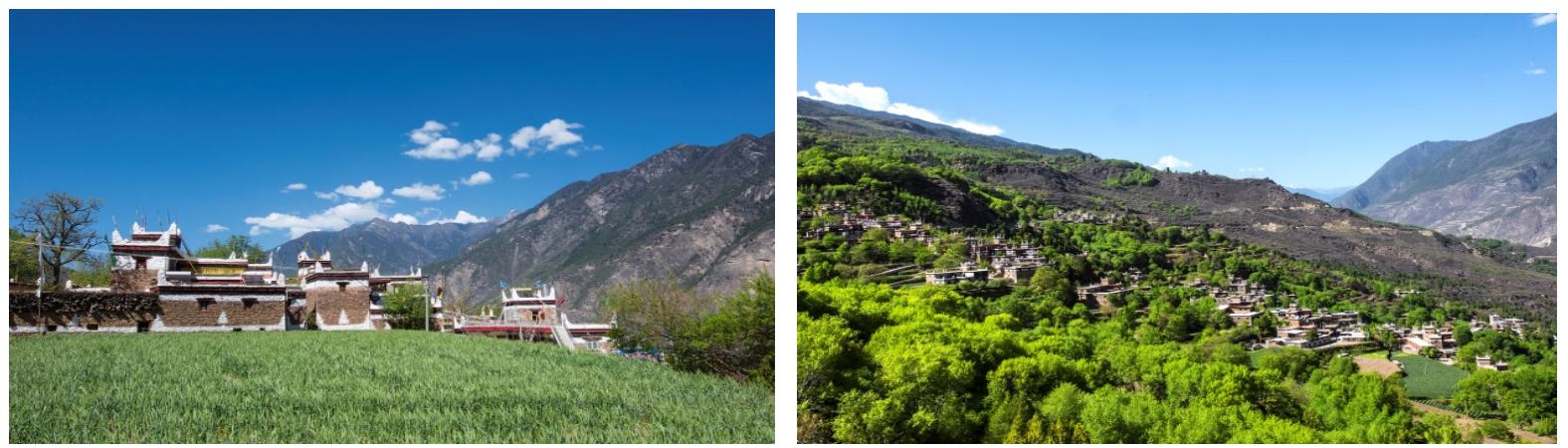

Figure 1. Photos of Jiaju Tibetan Village, 2017. 
Hiroshima city brand and achieving the city's regeneration [18].

The administration and construction of scenic spots in Tibetan villages in China usually follow the "government-led" model. Scholars have generally recognized the influence of community participation on tourism development. For example, Yun (2007) points out the shortage and problems of community participation, Ying (2012) puts forward a method to promote community participation. In recent years, researchers have begun to study the relations between scenic image planning and local residents. For example, Tianling (2007) points out that tourists' views are important factors for local residents to review their own culture anrism and planning, Yun (2014) points out that at the time of the traditional houses for tourism development, overall protection should be carried out for the entire village residential groups [5]. However, researchers usually failed to realize that one of the important factors that influence tourist's view is the selection and promotion of traditional culture by local residents. This is also an important factor to form the destination brand.

\section{Study Area and Methodology}

\subsection{Study Area}

The study area is Jiaju Tibetan Village, which covers an area of about 5 square kilometers and has 149 traditional Tibetan residential buildings. The village is located in Danba County in Sichuan Province of China, on the southeastern edge of the Qinghai-Tibet Plateau. The unique Tibetan architecture, clear rivers and verdant valleys form a beautiful village landscape (Figure 2).

\subsection{Questionnaires and Datas}

In February 2014, we visited 73 families and completed 41 valid questionnaires. In the survey, $54 \%$ were male, $46 \%$ were female. The Age structure of the survey is: 20 years old (37\%), 20 - 40 years old (35\%), 40 - 60 years old (15\%), and the

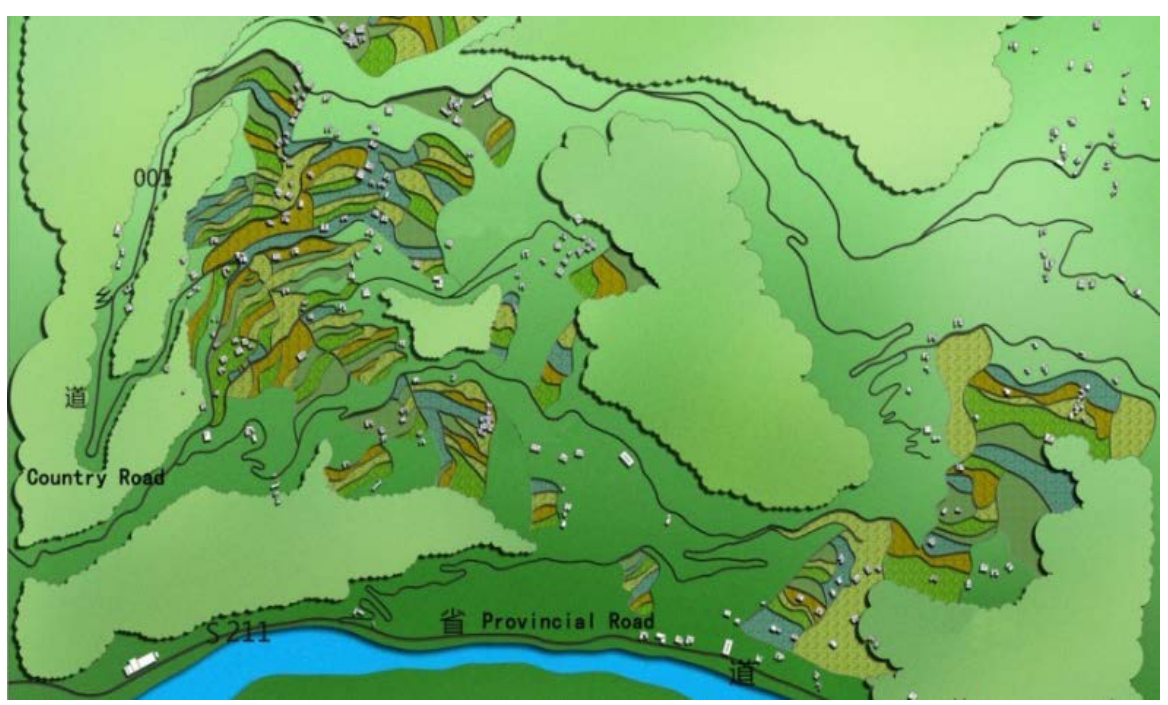

Figure 2. Map of Study Area, Jiaju Tibetan Village. 
rest is more than 60 years old. $90 \%$ of respondents lived in Jiaju more than 10 years. 7\% of respondents lived in Jiaju 5 - 10 years. No respondents lived less than 2 years in Jiaju. This shows that in JiaJu village villagers usually directly run family inns or restaurants. It's in the beginning period of community involvement in tourism development, rather than in the over-commercialization period. According to the survey (Table 1): (A) 73\% of the respondents believed that Tibetan Village revamped better than before, $20 \%$ of respondents remained neutral, and only $7 \%$ held the negative attitude; (B) more than $50 \%$ of the respondents were satisfied with the present, less than $10 \%$ of respondents opposed. This shows that house renovation and reconstruction in Jiaju not only promoted economic development, but also brought convenience to residents' daily lives.

\section{Results and Discussion}

\subsection{The Changes of House Locations}

Due to geographical occlusion, economic development in Jiaju Tibetan Village is lagging behind over a long period of time. Before the development of tourism, most of the residents lived a self-sufficient life. Local economy mainly depended on the agricultural sector, including planting fruit trees and crops, animal husbandry, and so on.

Houses in Jiaju Tibetan Village have various bright colors and unique shapes. Because of affinity or consanguinity, houses relatively gathered into smaller stockade, freely located at the foot of Kapama mountain. The entire settlement scattered following a certain rule, constituting the typical landscape of Gyarong Tibetan villages. After compiling an overall tourism development planning framework and improving road infrastructure by the government of Danba County in 2000, more and more tourists came to visit Jiaju Tibetan Village. During only 15 years, the tourism development in Jiaju Tibetan Village leaped from the exploration phase to the overall public participation phase as a minority tourist destination.

\subsection{Tourism Development Changed the Spatial Structure of the Village in Two Ways}

Firstly, the overall scale of Jiaju Tibetan Village has expanded, and new houses mostly located along the main roads, instead of the kinship-based and worship-based location choice method: 1) According to local tradition, when a new house was going to be built, the residents needed to ask priests mercy first, and the site selection would be based on religious beliefs. But in recent years, along with economic development and the residents' stronger awareness of the commodity

Table 1. Survey analysis of residential remodeling.

\begin{tabular}{lcccc}
\hline \multicolumn{1}{c}{ DISCLOSURE } & Approval & Neutral & Opposition & Total \\
\hline A. The Village is better than before & $30(73 \%)$ & $8(20 \%)$ & $3(7 \%)$ & $41(100 \%)$ \\
B. Be satisfied to today's Village & $21(51 \%)$ & $13(32 \%)$ & $7(17 \%)$ & $41(100 \%)$ \\
\hline
\end{tabular}


economy, during house site selection process, religion and culture is no longer the crucial factors. 2) Meanwhile, the number of residents who involved in catering, accommodation, tour guiding and other services continued increasing, while the agricultural population gradually decreased. Some residents also bought a car for personal use, procurement and tourist shuttle service. Car owners' hoped to live closer to main roads. 3) Therefore, after the start of tourism development in 2005, when local residents constructed their new houses, they would give more consideration to the convenience of transportation. The proximity to main roads could facilitate to manage a hotel or other commercial activities. There are three motorized road in Jiaju Village, which were renovated for the tourism development based on the original roads. New houses in this village mainly located along these three roads.

Secondly, the density of buildings in Jiaju Village increased: 1) The main cause of increased building density is in the process of tourism development, the residents began to build more houses on a large scale, in order to increase the number of beds of family hotel. In part 3.2, detailed discussion will be brought forward to analyze how the residents selected and interpreted symbols of national culture in house renovation and new-built process, as well as their role in the construction of the destination brand. 2) Besides several residents' new houses, other new buildings are mostly tourist facilities. One of the largest new buildings is a tourist center. The original shooting zone and place of execution have been gradually transformed into public space, providing space for the villagers to share feelings, and also becoming an important place for the preparation of village folk festivals and important game events. 3) Existing important buildings which attracted more tourists got better maintenance, such as the Turning Tower and the Red Army headquarters. However, for the Watch Towers which attracts fewer tourists, weathering damage has emerged.

\subsection{The Selection and Promotion of Traditional Elements in House Transformation}

The government did not introduce a standardized method of retrofitting houses for local residents in Jiaju. Jiaju is a typical Gyarong Tibetan village, and the traditional houses are generally divided into three floors: the first floor is used for livestock and stacking tools, the second floor is the main living space, the top level is the balcony and the Church area, and the roof corners placed with white stones. The traditional houses don't have special reception room for tourists. Therefore, the government put forward the "three changes a building" project in 2004 to promote the opening of family inn. The goal brought forward by local government is to build a new three-star hotel, to develop family inns, and to reach the reception capacity of 6100 person per day. The plan did not involve house renovation or reconstruction out looking requirements.

Following this plan, the residents began to build more houses and to carry on more tourism reception work. Because of the increase of tourists' volume, the 
scale was also expanding in traditional houses. For the government did not introduce a standardized method of retrofitting houses, most villagers imitated the pioneers of house renovation cases in the village, including "three sisters" house, the village chief's house and Guohua Zeng's house. Three Sisters' house is the first house to open the family inn, and the owner Three Sisters got supports from individuals and agencies outside the village. Guohua Zeng is a photographer, having a good knowledge of local history, music and culture tales. He is also one of the residents who started the family inn. These three families played an important role in community involvement in the tourism development process. Common houses additional methods can be grouped into three types: the viewing platform houses, Zeng Guohua residential home and Zhawachuo's home (Table 2). Newly built parts and original building are well integrated, constituting a new landscape for the village.

As Figure 3 shows, the additional parts retained traditional architectural elements such as shape, color, materials, sharp corners, windows, etc. Addition parts of the wall were built following the original pattern wall hangings, ribbons, white head and horn windows. The additional rooms are generally used as tourists' rooms, usually located on the second floor and the third floor. To protect their religious and cultural beliefs, the Church will be moved to the top of the building to show respect. The Tibetan residents in this village normally do not wear clothes, do not use the Tibetan bed, and the paintings and decorates indoor are not so much due to the long term influence by the Han culture. But during the renovation process, the residents added much Tibetan religious related paintings and decorations, and they used Tibetan bed and decorated with traditional Tibetan dress to meet tourists' expectations and imagination.

\subsection{The Introduction of Modern Elements and Techniques in House Transformation}

Modern elements and techniques were introduced during the house transforming. Firstly, some residents built new rooms around their old houses, setting up a clean and convenient bathroom. However, the traditional building techniques cannot meet the requirements of the standard room for drainage, so local residents started to use modern building materials such as cement in the standard room. Secondly, traditional clay floor become soft after the rain, and it's inconvenient for

Table 2. Representative methods of additional dwellings.

\begin{tabular}{|c|c|c|}
\hline Type & Methods & Characteristics \\
\hline $\begin{array}{l}\text { the viewing } \\
\text { platform houses }\end{array}$ & $\begin{array}{l}\text { Adding to the southwest direction, } \\
\text { build a new "L" shaped house }\end{array}$ & Forming a courtyard \\
\hline $\begin{array}{l}\text { Guohua Zeng } \\
\text { house }\end{array}$ & $\begin{array}{l}\text { Adding the east side of the house, } \\
\text { build a modern standard room }\end{array}$ & $\begin{array}{l}\text { The additional parts meets the } \\
\text { requirement of the facilities, convenient } \\
\text { and practical, popular with guests }\end{array}$ \\
\hline $\begin{array}{l}\text { Zhawachuo's } \\
\text { house }\end{array}$ & Build a new "L" shaped house & $\begin{array}{l}\text { Have broad vision and unified } \\
\text { architectural style }\end{array}$ \\
\hline
\end{tabular}




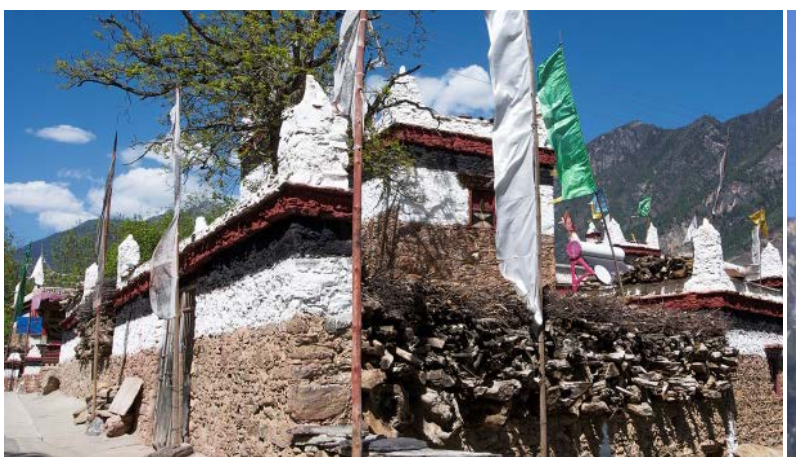

(a)

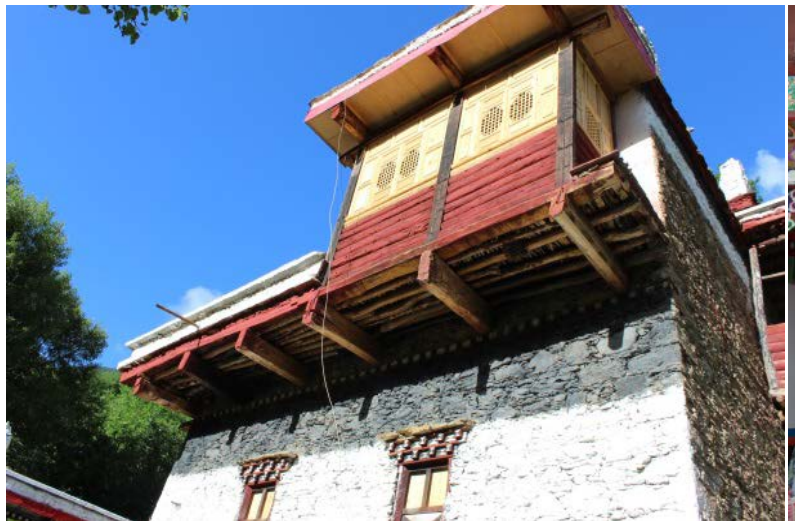

(c)

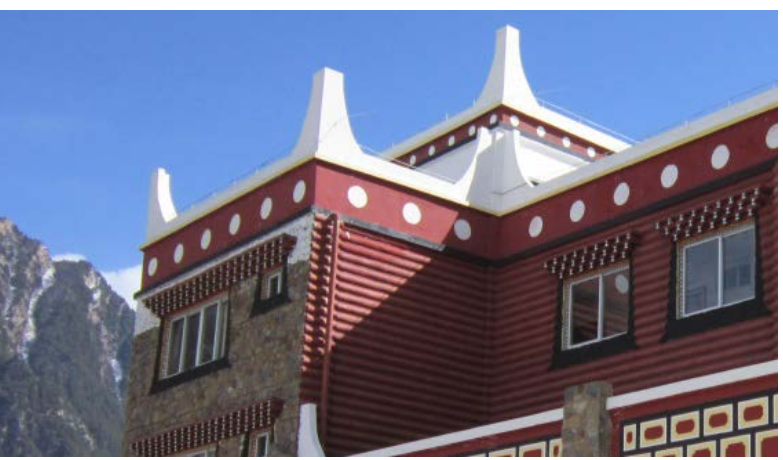

(b)

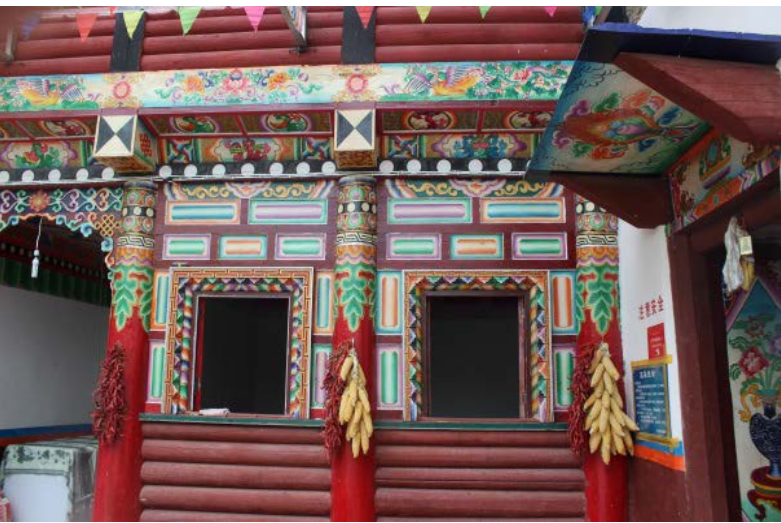

(d)

Figure 3. Traditional elements in houses. (a) Ribbons on the wall; (b) White stones on the top; (c) Traditional materials and colors; (d) Traditional decorations.

visitors to walk. Thus residents started to use cement on the balcony and roof, and also concrete, panels and other modern building materials to meet the needs of the tourists. Thirdly, the villagers also generally installed solar water heaters and the network wires in the additional buildings.

The newly built building is generally for tourist reception. For its construction period is usually very short, it's difficult to use traditional building techniques to build up. And such a "quick buck" type of construction somehow destroyed the local architectural traditions. Newly built concrete building is only to mimic traditional houses by using colors and decorative coatings. Solar water heaters provided by the Government seems out of place in the strong sunlight, affecting the landscape of the village. However, the contribution of these modern elements on Residents' participation in tourism development cannot be ignored.

\subsection{The Local Residents' View on House Location Changes and House Transformation}

According to the survey and investigation, we selected the top residential color ribbon, Tau windows, white stones placed on the corners, interior painting exterior wall surface pattern as the local characteristics of four residential elements. Most villagers believe the order of local characteristics elements is: the top ribbon pillbox Whitehead placed top corners, hand-painted interior and exterior walls. 
Most residents do not think Tau window can represent local characteristics, probably because Tau window is introduced after the development of tourism.

By renovation, the houses in Tibetan Village not only meet the needs of tourists, but also improve their standard of living. The villagers want to modernize several parts of existing village. According to the survey, the parts local villagers want to modernize include: public cultural facilities, meeting places, their own homes, the landscape, iconic buildings and so on. These parts are mostly the tourist gathering places.

Based on the above findings, it is found that the village landscape and ethnic customs that residents shows to visitors are not equivalent to their real life, and it related to a certain commercial objective. It also shows that one target of the ethnic tourism development is to lead to the rapid economic development of ethnic areas, and commercialization is a development trend of the destination.

\section{Conclusions}

The research shows that tourism development has a profound impact on the Jiaju Tibetan village. Firstly, the village scale became much larger during the past 10 years. Tourism influenced the location of new houses. Secondly, to increase the accommodation capability, most of the villagers carried out their own house renovation or additions to open family inn. And the development of tourism brought better protection of the dilapidated important buildings in the village. Thirdly, the villagers preserve and enhance the existing architectural elements, such as residential appearance, ribbons, Tau windows and Whitestone, etc. They also use modern elements, such as non-traditional materials, new toilets, energy-saving facilities. Due to the lack of unified planning, the residence shape and construction methods show a trend of diversification. New buildings and the old buildings keep a uniform style, becoming a part of Jiaju's new landscape.

The study also found out community involvement played an important role in promoting the sustainable development of tourism destinations. Aboriginal residents are the direct successor of the local traditional culture, and are also the direct interest group of sustainable development of architecture and landscape. They keep a deeper understanding of regional landscape features. They hold the highest degree of consciousness and passion of the feature protection among a variety of protection participants. From a practical point of view, house additional parts are good places for welcoming visitors and increasing owner's income, and also for visitors to experience the culture. In view of foreground and background theory of tourism study, residents' houses become the foreground for revealing landscape and ethnic customs of visitors. Tourists could learn about the host culture in a short time, setting up its unique destination impression through the elements shown in resident's house.

\section{Acknowledgements}

The study is supported by the National Natural Science Foundation of China 
(51508484), the Education Reform Funding of Southwest University for Nationalities (2015ZD03), Sichuan Social Science Planning Foundation (SC17TJ009), and Sichuan Social Science Major Research Center Foundation for County Economic (XY2017019).

\section{Conflicts of Interest}

The authors declare no conflicts of interest regarding the publication of this paper.

\section{References}

[1] Liu, Y. (2007) Rural Tourism Social Impact on the Minority Community-A Case Study in Danba Jiaju Tibetan Village. Social Sciences, No. 6, 77-79.

[2] Liu, W. (2010) Plight of Ethnic Communities in Tourism Development: Theoretical Interpretation and Empirical Analysis-A Case Study in Danba Jiaju Tibetan Village. Yunnan Normal University (Philosophy and Social Sciences), No. 1, 142-147.

[3] Lan, Y. and Zhou, Z.L. (2012) Danba JiaJu Tibetan Community Participation in Tourism Development and Promotion Methods. Economic Research Guide, 18, 231-232.

[4] Zhong, J., Li, R.J. and Tang, Y. (2013) Research in Sichuan Ethnic Villages Regulatory Mechanisms of Social Conflict Tourism-A Case Study in Danba Jiaju Tibetan Village. Research and Development, No. 3, 65-68.

[5] Liu, Y. (2014) Traditional Houses under the Protection of Minority Villages Travel Background-A Case Study in Danba Jiaju Tibetan Village. Southwest University for Nationalities (Humanities and Social Sciences), No. 2, 155-158.

[6] Sun, J. (2005) Tibetan Villages' Relationship between Residential Buildings and the Natural Environment. Aba Teachers College School, 22, No. 4.

[7] Smith, M.K. (2009) Issues in Cultural Tourism Studies. 2nd Edition, Rougtledge. https://doi.org/10.4324/9780203869857

[8] Xu, J.F. (2005) Tourism Culture and Cultural Tourism: Issues of Theory and Practice. Tourism Tribune, No. 4, 67-72.

[9] Liu, W. and Xue, W. (2008) Microscopic Mechanisms Involved in Minority Areas of Community Tourism-A Case Study in Danba Jiaju Tibetan Village. Sichuan Normal University (Social Sciences), No. 2, 140-144.

[10] Ritchie, J. and Crouch, G.I. (2000) The Competitive Destination: A Sustainable Perspective. Tourism Managemen, 21, 1-7.

[11] Morrison, A. and Anderson, D. (2002) Destination Branding. http://www.macvb.org/intranet/presentation/DestinationBrandingLOzarks6-10-02. ppt

[12] Cai, L. (2002) Cooperative Branding for Rural Destinations. Annals of Tourism Research, 29, 720-742. https://doi.org/10.1016/S0160-7383(01)00080-9

[13] Kavaratzis, M. and Ashworth, G.J. (2005) City Branding: An Effective Assertion of Identity or a Transitory Marketing Trick? Tijdschrift Voor Economische en Sociale Geografie, 96, 506-514. https://doi.org/10.1111/j.1467-9663.2005.00482.x

[14] Hankinson, G. (2007) The Management of Destination Brands: Five Guiding Principles Based on Recent Developments Incorporate Branding Theory. Journal of Brand Management, 14, 240-254. https://doi.org/10.1057/palgrave.bm.2550065

[15] Gilmore, F. (2002) A Country-Can It Be Repositioned Spain-The Successstory of 
Country Branding. Journal of Brand Management, 9, 281-293.

https://doi.org/10.1057/palgrave.bm.2540078

[16] García, J.A., Gómez, M. and Molina, A. (2012) A Destination-Branding Model: An Empirical Analysis Based on Stakeholders. Tourism Management, 33, 646-661. https://doi.org/10.1016/j.tourman.2011.07.006

[17] Freire, J.R. (2009) "Local People" a Critical Dimension for Place Brands. Journal of Brand Management, 16, 420-438. https://doi.org/10.1057/palgrave.bm.2550097

[18] Wu, C.T., Funck, C. and Hayashi, Y. (2014) The Impact of Host Community on Destination (re)Branding: A Case Study of Hiroshima. International Journal of Tourism Research, 16, No. 6. https://doi.org/10.1002/jtr.1946 